\title{
Design of Main Bridge of Second Penang Bridge in Malaysia
}

\author{
Hou Man ${ }^{1}$, Liu Bo ${ }^{2}$, Peng Yun Dong ${ }^{3}$, Chang Chung Man ${ }^{2}$ \\ ${ }^{1}$ CCCC Highway Consultants Co., Ltd. (Hainan Office), Haikou, China \\ ${ }^{2}$ CCCC Highway Consultants Co., Ltd., Beijing, China \\ ${ }^{3}$ International Business Department, CCCC Highway Consultants Co., Ltd., Beijing, China
}

Email address:

houman@hpdi.com.cn (Hou Man), liubo@hpdi.com.cn (Liu Bo), pengyundong@hpdi.com.cn (Peng Yun Dong), sam1083@hotmail.com (Chang Chung Man)

\section{To cite this article:}

Hou Man, Liu Bo, Peng Yun Dong, Chang Chung Man. Design of Main Bridge of Second Penang Bridge in Malaysia. International Journal of Transportation Engineering and Technology. Vol. 4, No. 2, 2018, pp. 35-42. doi: 10.11648/j.ijtet.20180402.13

Received: June 22, 2018; Accepted: July 12, 2018; Published: August 9, 2018

\begin{abstract}
The main bridge of the Second Penang Bridge in Malaysia [1-2] is a two-pylon three-span prestressed concrete cable-stayed bridge, with span arrangement of $(117.5+240+117.5) \mathrm{m}$. The pylons and the main girder are monolithic. The main girder, which is $34.6 \mathrm{~m}$ wide, adopts the ladder type concrete deck section comprising top slab, transverse diaphragms and edge beams. The pylons are H-form pylons, and the stay cables are formed of parallel strands and are arranged in fan cable planes. Each pylon column carries 18 pairs of stay cables that are anchored by the deviation saddles in the pylons and anchor blisters in the main girder. The foundations consist of large diameter bored piles, varying from $2.3 \mathrm{~m}$ to $2.0 \mathrm{~m}$ in diameter. An optimized design scheme is tailored for the bridge, in which the main girder has the cross-section built up by a combination of slab, diaphragm and edge beam structuresand was constructed by using the rear supported form traveler and incorporating an optimization of construction timing. The scheme resolved the problems of load-bearing capacity verification for bridge deck and the verification of main girder prestress under the heavy vehicle loads prescribed in the BS5400. Meanwhile, a meticulous calculation method was put forward for the design and analysis of the main girder, to obtain the real load bearing conditions of the main girder and the bridge deck. The diaphragms were calculated by the spatial grillage analysis method, aimed at guaranteeing the load-bearing safety of the structure.
\end{abstract}

Keywords: Cable-Stayed Bridge, Ladder Type Deck, Spatial Grillage Analysis, Deviation Saddle, Rear-Supported Form Traveler, Design

\section{Project Introduction}

The Malaysian Second Penang Bridge [1-2], connecting the south of Penang Island and peninsula of Malaysia,has a total length $22.5 \mathrm{~km}$ in which about $16.5 \mathrm{~km}$ is the marine bridge. The bridge deck carries dual carriageways comprising 4 traffic lanes and 2 motorcycle lanes and has a width $29.8 \mathrm{~m}$ at typical deck section. The British Standard was used for the bridge design.

The main bridge is a cable-stayed bridge [3-4] with a prestressed concrete deck girder supported by two planes of cables. The span arrangement is $117.5 \mathrm{~m}+240 \mathrm{~m}+117.5 \mathrm{~m}$ with a side span to main span ratio of 0.49 . The main girder, $34.6 \mathrm{~m}$ in width, is in the structural form of ladder type deck consisting of top slab, diaphragms, and edge beams all in concrete structures. The pylon is in H-shaped and the deck girder is cast monolithically into the pylon crossbeams. The parallel strand stay cables were employed with their anchorages at the pylons by means of cable saddles. Figure 1 shows the main bridge general arrangement.

\section{Design and Functional Requirements}

1) Bridge design life: 120 years

2) Design speed: $80 \mathrm{~km} / \mathrm{h}$

3) Bridge design loading: British Standard (BD37/01, Loads for Highway Bridges)

4) Gradient: Bridge maximum longitudinal fall $3.0 \%$, maximum crossfall $2.5 \%$

5) Design water level for navigation: Highest $+2.600 \mathrm{~m}$ (ACD), lowest $+0.600 \mathrm{~m}$ (ACD)

6) Main bridge navigation clearance: $150 \mathrm{~m} \times 30 \mathrm{~m}$

7) Basic wind speed: $27 \mathrm{~m} / \mathrm{s}$ 
8) Seismic design:Two seismic design evaluation levels considered. Level 1 (Design earthquake) 475 years return period, peak ground acceleration $0.072 \mathrm{~g}$; Level 2 (Maximum credible earthquake) 2500 years return period, peak ground acceleration $0.109 \mathrm{~g}$.
9) Ship collision: Main navigation channel for the passage of the 4500DWT vessel, the main bridge pylon foundation to resist ship impact force $27.6 \mathrm{MN}$, transition pier foundation to resist $6 \mathrm{MN}$ and all remaining marine piers to resist $1 \mathrm{MN}$.

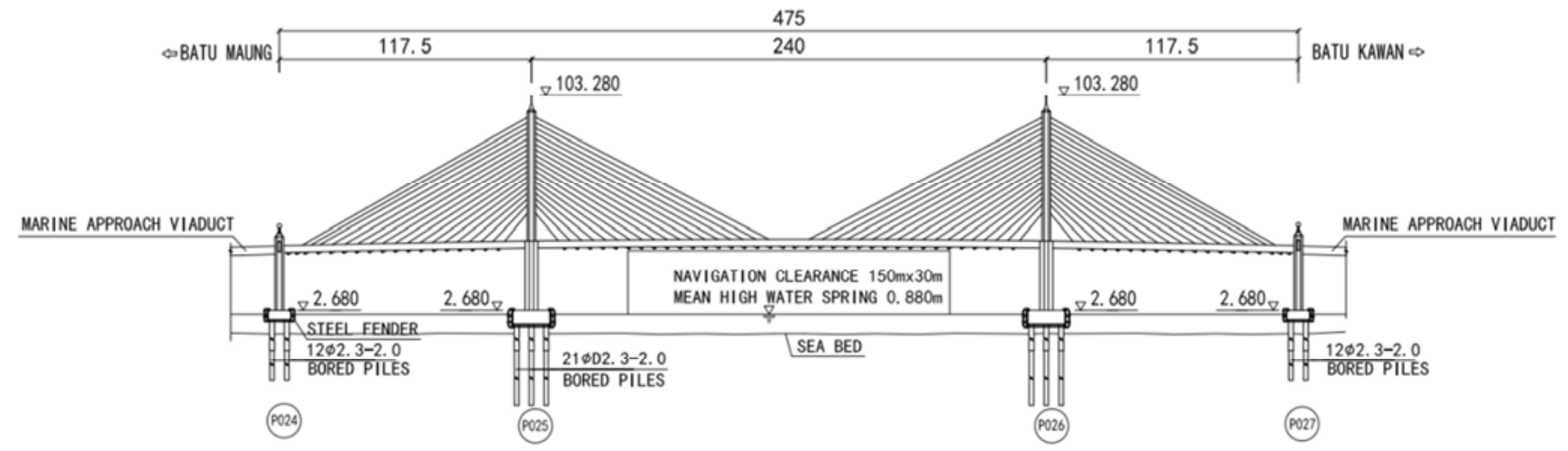

Figure 1. Main Bridge General Arrangement.

\section{Comparison of British and Chinese Design Standards}

The Second Penang Bridge, to represent the "going out" of China's transportation, all the design processes are extremely stringent. The Employer required the design to comply with the British Standard which is significantly different from the Chinese Standard. Differences between British and Chinese Standards in bridge design loadings and prestressed concrete structure design are introduced in the following sections for future British Standard project design reference.

\subsection{Design Loading}

The major difference between British and Chinese Standards in design loading is the traffic loading where the design load intensities and traffic lane factors are much larger in the British
Standard. Due to limited space in this paper, only brief introduction to the British Standard traffic loading and lane factors is given for the sake of comparison with Chinese Standard.

The British Standard specified the highway traffic loading consisting of HA and HB loads. HA loading is the regular traffic live load, similar to that in the Chinese Standard, includes two parts the uniform distributed and concentrated loads. The uniform distributed load is evaluated using the following formula:

$$
\begin{aligned}
& \mathrm{W}=336(1 / \mathrm{L})^{0.67}(\mathrm{~L}<=50 \mathrm{~m}) \\
& \mathrm{W}=36(1 / \mathrm{L})^{0.1}(50 \mathrm{~m}<\mathrm{L}<1600 \mathrm{~m})
\end{aligned}
$$

where, $\mathrm{W}=$ load intensityin notional lane $(\mathrm{kN} / \mathrm{m})$

$\mathrm{L}=$ loaded length calculated based on influence line (m)

The HA concentrated load (called KEL in British Standard) is $120 \mathrm{kN}$ per notional lane.

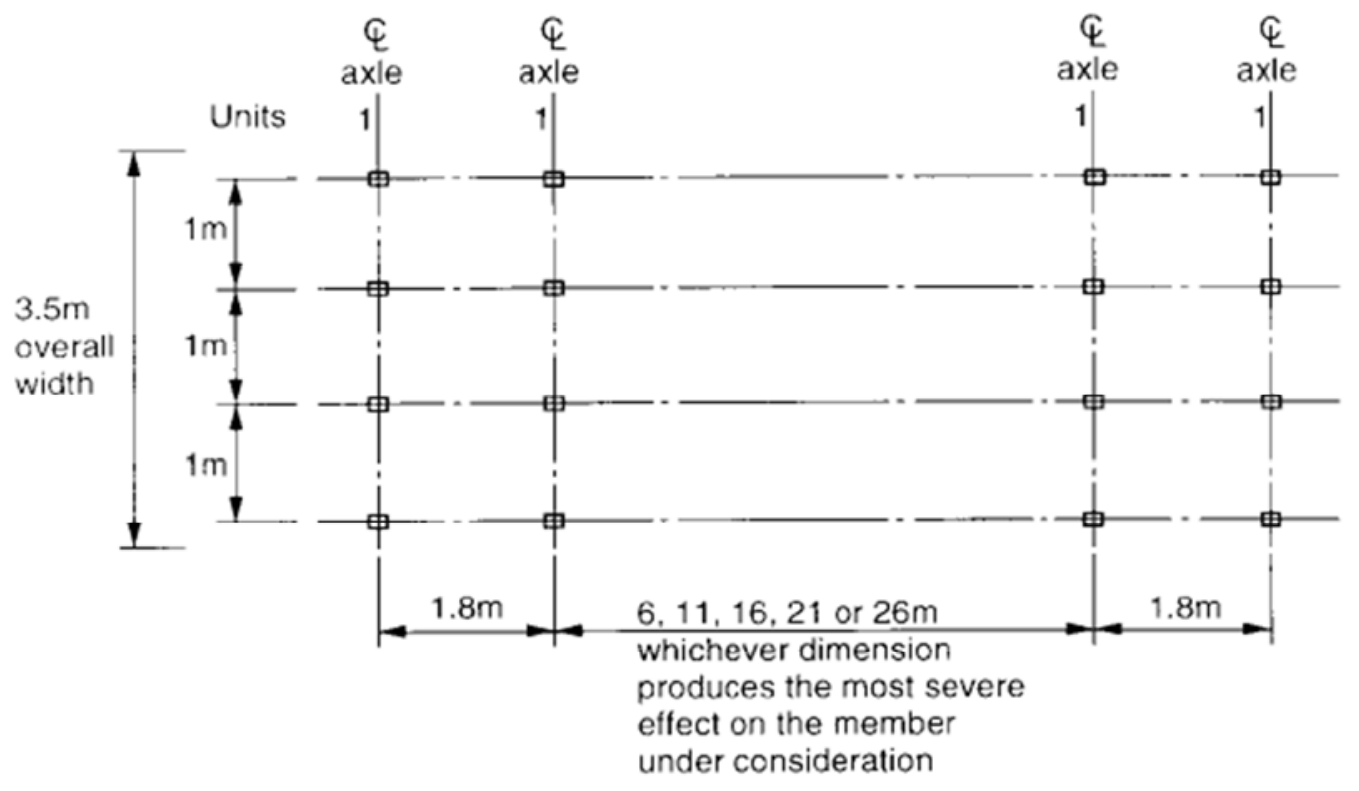

Figure 2. Dimensions of HB Vehicle. 
HB load is a special traffic live loading which is similar to the trailer loading as specified in the Chinese Standard "JTJ 021-85 Highway Bridge\& Culvert Design Code". Thedimensions of $\mathrm{HB}$ vehicle are as shown in Figure 2 [5], in which1 unit of HBhas a single axle load $10 \mathrm{kN}$ and single wheel load $2.5 \mathrm{kN}$. In the design, both 30 and 45 units of HB need to be considered. HB 30 units represent a single axle load $300 \mathrm{kN}$ and a single wheel load $75 \mathrm{kN}$. HB 45 units represent a single axle load $450 \mathrm{kN}$ and a single wheel load $112.5 \mathrm{kN}$.

The lane factor adopted in British Standard BD37/01 is different from that specified in the Chinese Standard "JTG D60-2004 Highway Bridge and Culvert Design Code". Take the bridge span $240 \mathrm{~m}$ as an example, the comparison of BD37/01 HA load and JTG D60-2004 Highway-Class I load is indicated in Table 1 which revealed that the HA load is 2.64 times of the load specified in Chinese Standard.

Table 1. Comparison of BD37/01 HA Load and JTG D60-2004 Highway-Class I Load.

\begin{tabular}{lllll}
\hline & Load intensity in one notional lane $(\mathbf{k N} / \mathbf{m})$ & Notional lanes/ nos. & Multiple lane factors & Multiple lane load intensity \\
\hline (1)BD37/01 & 20.81 & 6.0 & 4.40 & 91.56 \\
$(2)$ Highway Class I & 10.50 & 6.0 & 3.30 & 34.65 \\
$(1) /(2)$ & 1.98 & 1.0 & 1.33 & 2.64 \\
\hline
\end{tabular}

Note: For ease of comparison, the concentrated load is not taken into account.

\subsection{PrestressedConcrete Design Requirements in British Standard}

In the BS5400 Steel, Concrete and Composite Bridges: Part 4Code of practice for design of concrete bridges [6], it is specified that tension is not allowed in the prestressed concrete structure under ultimate limit states load combinations: i) dead load + 1.2HA, and ii) dead load + HA+ 1.1 HB30. That means tension is not allowed whenever the concrete structure is provided with prestressing steel. However, in the Chinese Standard "JTG D62-2004 Highway Reinforced and Prestressed Concrete Bridge and Culvert Design Code", there is the prestressedstructural element not allowed tensile stress and also Class A \& B prestressed structural elements allowed tensile stress in members. Due to the difference in the prestressed concrete structural design requirement in two standards, the conventional prestressed concrete ladder type deck cable-stayed bridge with its deck top slab provided with prestressing tendons cannot be directly applied in this project.

\section{Main Deck Girder Design}

\subsection{Main Deck Girder Cross Section}

In order to minimize the construction difficulties, reduce the cost and assure work quality, the main girder adopted the ladder type deck structure [7]. The prestressed concrete main bridge deck is $34.6 \mathrm{~m}$ wide and $475 \mathrm{~m}$ long and adopted Grade C55 high performance concrete. To abate the wind resistance coefficient of the main girder, the outer surface of edge beam is in the double folded shape. The main girder has a span-to-depth ratio of $1: 169.8$ and a span-to-width ratio of 1:6.9. The two longitudinaledge beams are 2.8 mdeep and connected by $350 \mathrm{~mm}$ thick transverse diaphragms in prestressed concrete spaced at $6 \mathrm{~m}$ centers. The deck top slab is $280 \mathrm{~mm}$ thick, continuously spanning over the transversediaphragms. Thetypical deck girder cross section isshown in Figure 3.

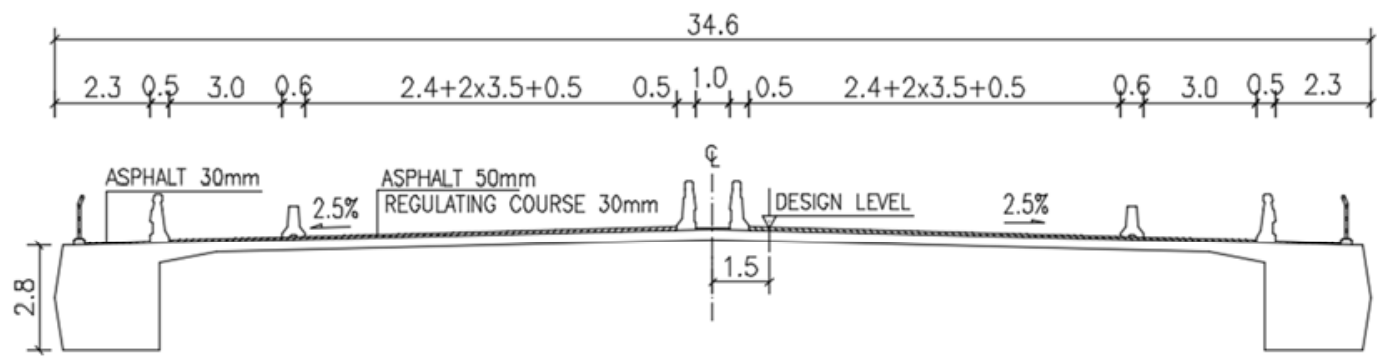

Figure 3. Main Deck Girder Typical Cross Section (Unit: m).

The heavy BS traffic loading and wide deck girder section with edge beams, diaphragm, and top slab structures did bring about two difficulties to the bridge design:

(1) The conventional ladder type deck cross section commonly adopted in projects in China cannot be applied to this bridge. As for the deck top slab design, the typically adoptedprestressing tendon comprising 5 nos. $15.7 \mathrm{~mm}$ strands at spacing $750 \mathrm{~mm}$ in other similar bridge structures in China is far away from the required"no tension" as specified in British Standard.For the edge beam design, based on the conventional Chinese common design philosophy of prestressing force applied on the entire section, the deck top slab would resist part of the prestressing force effect and result in reduction in prestressing level at the edge beams, and hencedifficult forthe edge beam to have sufficient compressive stress to satisfy the design requirement. 
(2) The shear lag effect is quite significant for the ladder type deck of width $34.6 \mathrm{~m}$ and a span-to-width ratio of 1:6.9. The support conditions were varying during the balanced cantilever erection stages and bridge completion and the deck slab effective width was also varying at the same time. The adoption of traditional single beam member and consideration of fixed effective width at the deck is not able to obtain the actual structural behaviors of the main girder and deck top slab.

In connection with the above two design difficulties, a "built up" bridge deck cross section and meticulous calculation method were put forward for the design and analysis of the main girder.

\subsection{1. “Built-up” Bridge Deck Cross Section}

In order to resolve the issues of deck top slab structural adequacy under heavy BS traffic loads as well as main deck girder stress check due to prestressing effect, the "built-up" bridge deck cross section was proposed. The key design features are as follows:

(1) Adoption of different structural types in the same cross section

To solve the issue of possible over stressing at the deck top slab, the edge beams were designed as prestressed concrete elements while the deck top slab was designed as reinforced concrete element. Through the provision of adequate reinforcements at the deck top slab, both deck slab structural and durability requirements can be fulfilled.

(2) Optimization of construction timing

The concrete of edge beams was placed first and then followed by stressing of longitudinal tendons at the edge beams such that the prestressing effect was concentrated at the edge beams. The top slab concrete was cast only after the edge beam construction completed so as to avoid deck slab to be cast simultaneously and this could eliminate the prestressing effect to top slab [8-9].

(3) Rear supported form traveler

The main bridge typical deck segments were constructed by using the rear supported form traveler. The edge beams were cast together with the deck top slab of the preceding segment such that the concrete of edge beams and deck top slab were placed and cured at the same time during one construction cycle. The deck construction was progressed in a manner that both construction time and procedures were saved, and also avoided a second time transition of the stay cable anchorage from the form traveler to the concrete deck. In the meantime, the delay in casting of top slab can effectively reduce the demand to the form traveler load carrying capacity [10] (Figure 4).

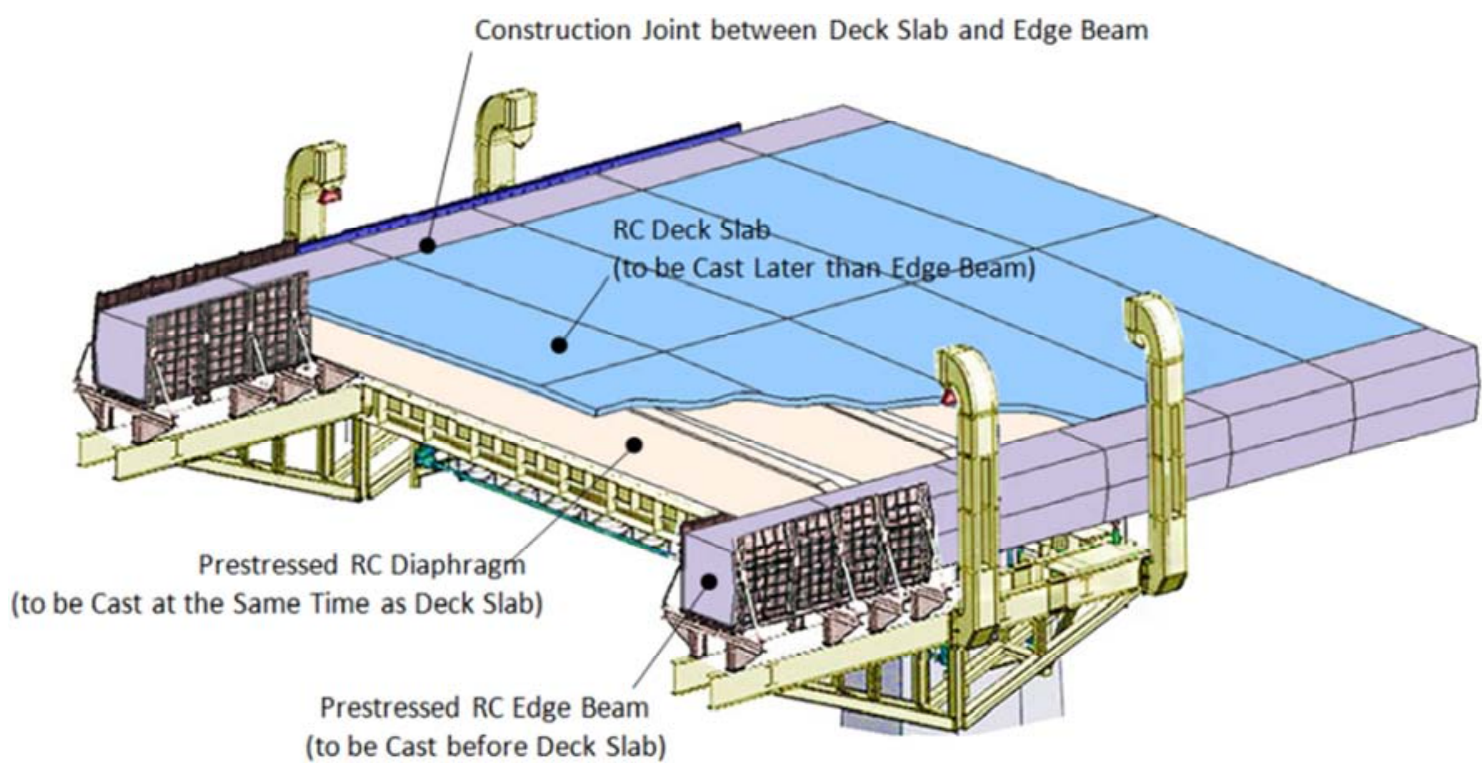

Figure 4. Rear Supported Form Traveler and Main Deck Girder Construction Sequence.

\subsubsection{Meticulous Method for Bridge DeckStructural Analysis}

The edge beam is in prestressed concrete while the deck top slab is in reinforced concrete, and the $34.6 \mathrm{~m}$ deck width caused quite a significant shear lag effect [11]. For the typical deck construction, the concrete of edge beams was placed first and then followed by stressing of longitudinal tendons at the edge beams such that the prestressing effect was concentrated at the edge beamsand this could eliminate the prestressing effect to top slab. The conventional single beam member analysis model cannot reveal the main deck structural behaviors. The balanced cantilever method was adopted for the deck erection and the cantilever length would increase during the construction progressed. If single beam member analysis model is used, it is unable to obtain the real internal forces and stresses at the edge beams and top slab.

The bridge deck structural analysis adopted the single beam model (Model A) and meticulous beam slab model (Model B) for evaluation of main deck internal forces. Model-A was used for the analysis of all structural member internal forces due toall load effectsfor the bridge completion stage (superimposed dead load, HA+HB30/45 traffic live load, motorcycle live load, temperature load, differential settlement, 
creep \& shrinkage etc.)[12]. Model-B was used to investigate member stresses due to dead load, longitudinal prestressing and stay-cable effects to the edge beams and deck top slab at the principal construction stages.

The major difference between Model A and B is in the simulation of main bridge deck. In Model-B, the entire deck section was divided into 10 elements transversely. The twoedge beams were modeled as line elements and the deck slab was modeled as 8 plateelements, and the remaining elements were modeled similarly after Model A. Model B is as indicated in Figure 5.

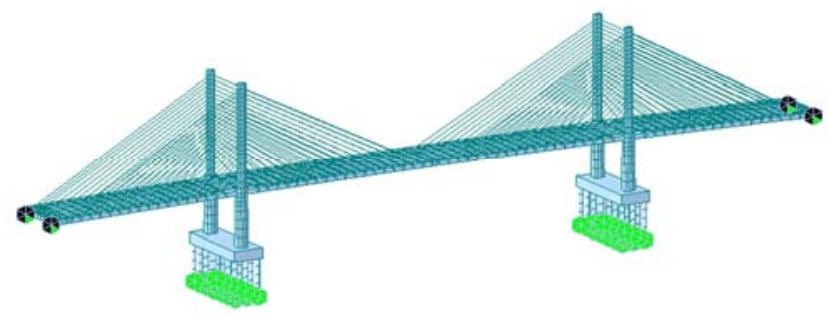

Figure 5. Structural Analysis Model B.

From the analysis results of Model B,the maximum tensile stress at the edge beam is $0.76 \mathrm{MPa}$ during the construction stages which is less than the limit $1.0 \mathrm{MPa}$ as specified in design standard [6]. The maximum compressive stress is $-21.5 \mathrm{MPa}$ which is less than $-22.0 \mathrm{MPa}$ as limited by the design standard[6].The edge beams of main deck girder have no tension under the SLS load combination I: \{Dead Load + 1.2 HA or Dead Load +1.1(HA+HB30) $\}$, and have a maximum tensile stress $1.06 \mathrm{MPa}$ (less than the design standard limit 2.67MPa[6]) under SLS load combination II: $\{$ Dead Load +1.0 HA +1.0 Wind Load or Dead Load $+1.0(\mathrm{HA}+\mathrm{HB} 45)+1.0$ Wind Load $\}$ and SLS load combination III: \{Dead Load $+1.0 \mathrm{HA}+1.0$ Overall Temp. Rise/Fall +0.8 Differential Temp. at Section or Dead Load $+1.0(\mathrm{HA}+\mathrm{HB} 45)+1.0$ Overall Temp. Rise/Fall +0.8 Differential Temp. at Section $\}$. The maximum SLS compressive stress at edge beam is $-21.80 \mathrm{MPa}$ which is less than $-27.5 \mathrm{MPa}$ as limited by the design standard[6]. For the deck top slab, the maximum crack width is $0.08 \mathrm{~mm}$ during SLS stage which is less than the allowable limit $0.15 \mathrm{~mm}[6]$. From all the results, the bridge deck is structurally safe.

\subsection{Transverse Diaphragm Design}

Since the bridge deck was erected by cast in-situ balanced cantilever method using form traveler, the weights of as-cast segmentsduring the progress of cantilever erection would affect the structural forces and deformations of subsequent segments to be cast. This would result in non-uniform forces in the diaphragms of the deck structure. The designer found the traditional simplified method and finite element solid modeling method is not able to accurately reflect structural behaviors and the restraints due to the edge beams, and also unable to cater for the cumulative forces onto the diaphragms contributed from structure self-weight, diaphragm prestressing and stay cable force during the progress of cantilever construction. Therefore, structural forces at the diaphragms may be underestimated and would result in an unsafe structure.

The designer put forward the consideration of spatial grillage analysis method at construction stages, and the load effects on each diaphragm are computed by the formula:

$$
S_{i}=\sum_{j=i}^{i+4} S_{G i, j}+\sum_{j=i}^{i+3} S_{P i, j}+\sum_{j=i}^{i+2} S_{C i, j}
$$

where: $\mathrm{S}_{\mathrm{Gi}, \mathrm{j}}=$ loading effect from the self-weight of the $\mathrm{j}^{\text {th }}$ segment on the diaphragm of the $i^{\text {th }}$ segment

$\mathrm{S}_{\mathrm{P}, \mathrm{j}}=$ effect of prestressing at diaphragm of the $\mathrm{j}^{\text {th }}$ segment onto the diaphragm of the $i^{\text {th }}$ segment

$\mathrm{S}_{\mathrm{C} i \mathrm{j}}=$ effect of tensioning of the $\mathrm{j}^{\text {th }}$ stay cable on the diaphragm of the $i^{\text {th }}$ segment

By using the above calculation method, the loading effects induced on the 1st to 10th diaphragms when constructing the 10th diaphragm (including diaphragm self-weight, prestressing at the diaphragm, tensioning the 10th pair stay cable) are indicated in Figure 6.

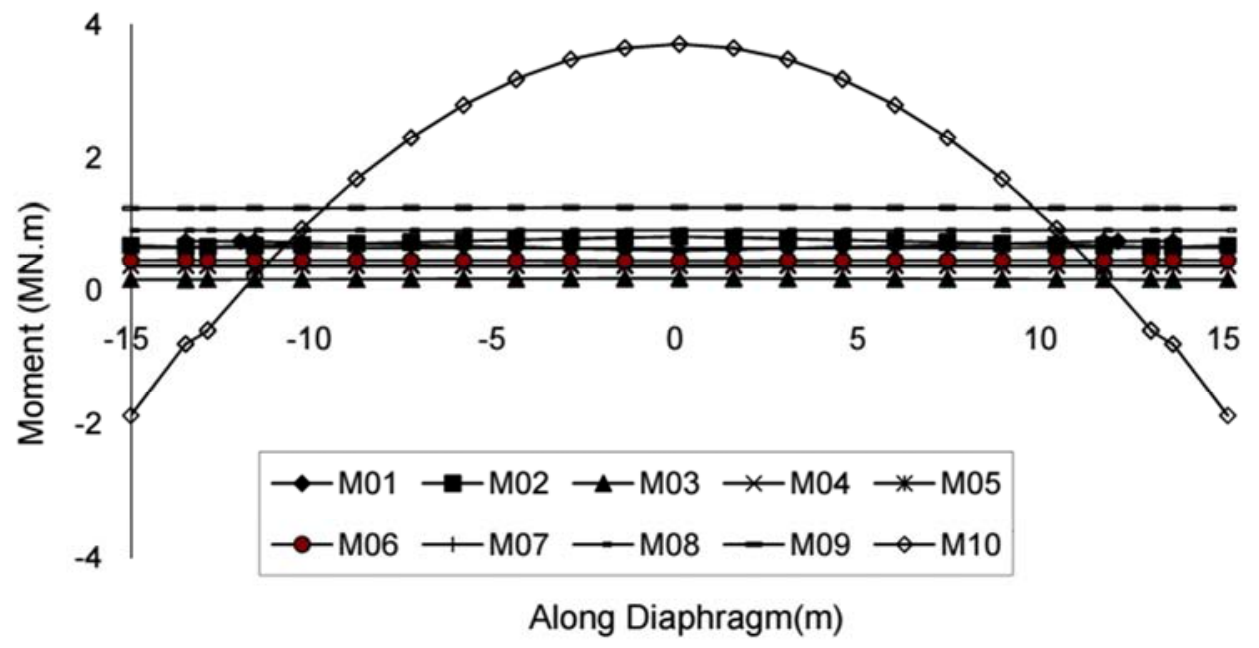

(a) Diaphragm $M_{10}$ self-weight induced moments at diaphragms $M_{1}-M_{10}$ 


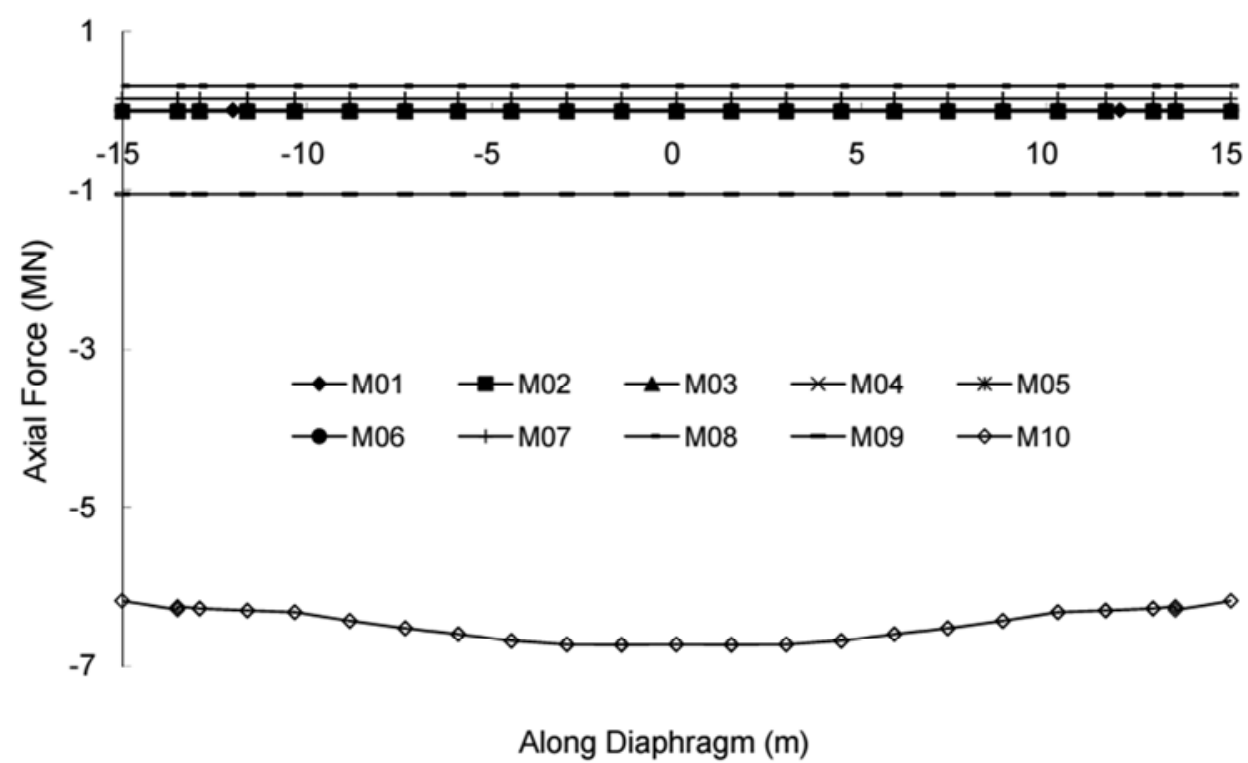

(b) Prestressing at diaphragm $M_{10}$ induced axial forces at diaphragms $M_{1}-M_{10}$

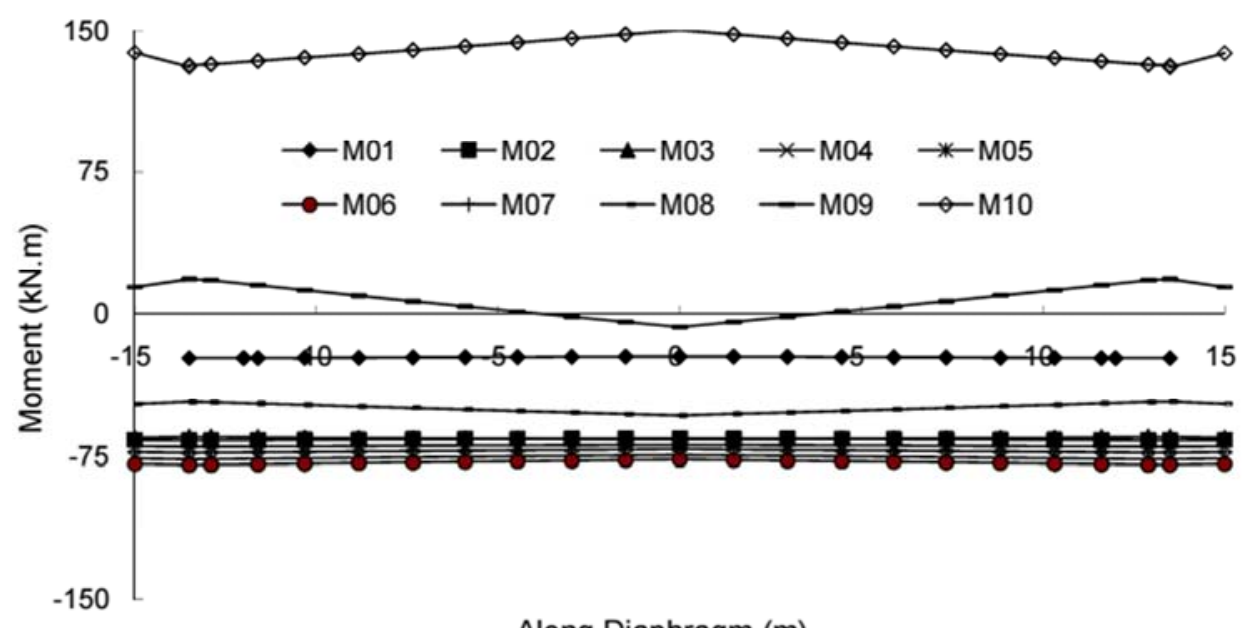

Along Diaphragm (m)

(c) Tensioning of Stay Cable $\mathrm{M}_{10}$ induced moments at diaphragms $\mathrm{M}_{1}-\mathrm{M}_{10}$

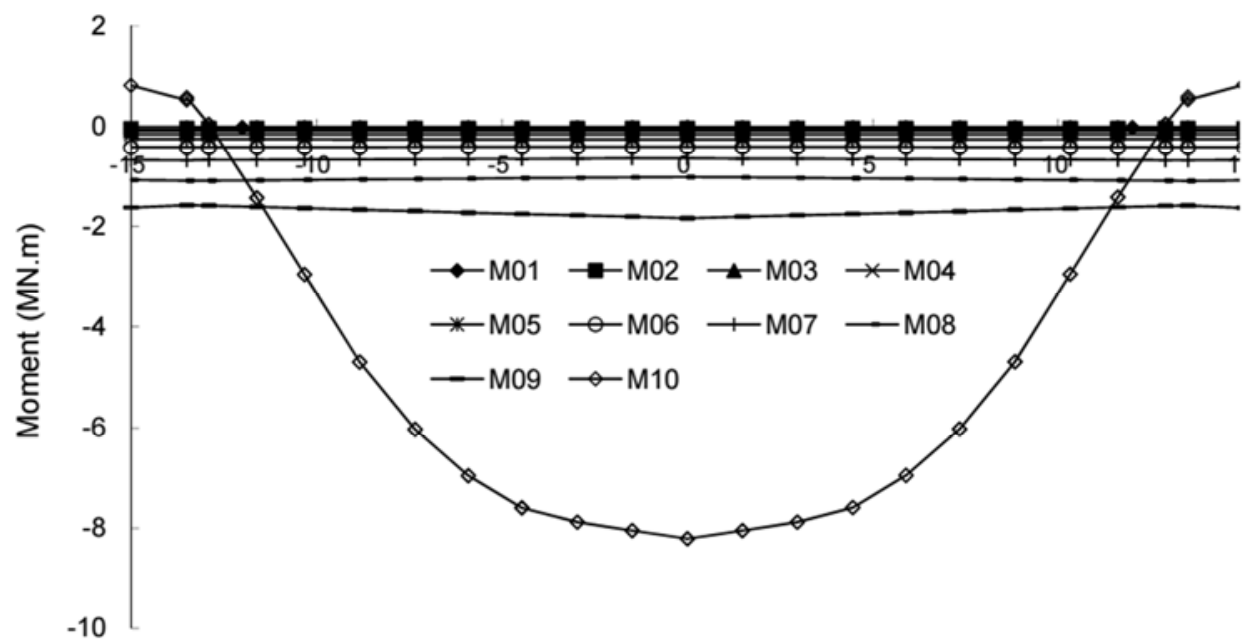

Along Diaphragm (m)

(d) Prestressing at diaphragm $M_{10}$ induced moments at diaphragms $M_{1}-M_{10}$

Figure 6. Loading Effects at Diaphragm $M_{1}-M_{10}$. 
From Figure 6, the construction of subsequent segments would affect the internal forces and deformations of the as-cast segments. The traditional single diaphragm simplified analysis method is not safe.

\section{Stay Cables and Anchorages}

\subsection{Stay Cable Design}

The main bridge has total 4 stay cable planes arranged in fan-shaped and each stay cable plane has 18 nos. of stay cables. The stay cables composed of high strength parallel strands of ultimate tensile strength $1860 \mathrm{MPa}$ and the area of each strand is $150 \mathrm{~mm}^{2}$. The stay cables are anchored on the main deck girder at the same positions as the diaphragms, i.e. $6 \mathrm{~m}$ center to center spacing. The stay cable no. 1 is heavier and has 55 nos. of strands. The stay cable nos. 2-18 are arranged with varying inclined angleand the numbers of strands increased from 37 nos. to 73 nos. gradually. In order for the stay cables to cross over the pylon, a deviation saddle is used. One continuous stay cable is adopted for crossing the pylon and supporting the main and side spans. The design life of stay cable is 50 years, adopting the replaceable third generation corrosion system (including zinc galvanized strands, individual HDPE sheath for each strand and sheathing for whole stay cable). The stay cable details are as shown in Figure 7.

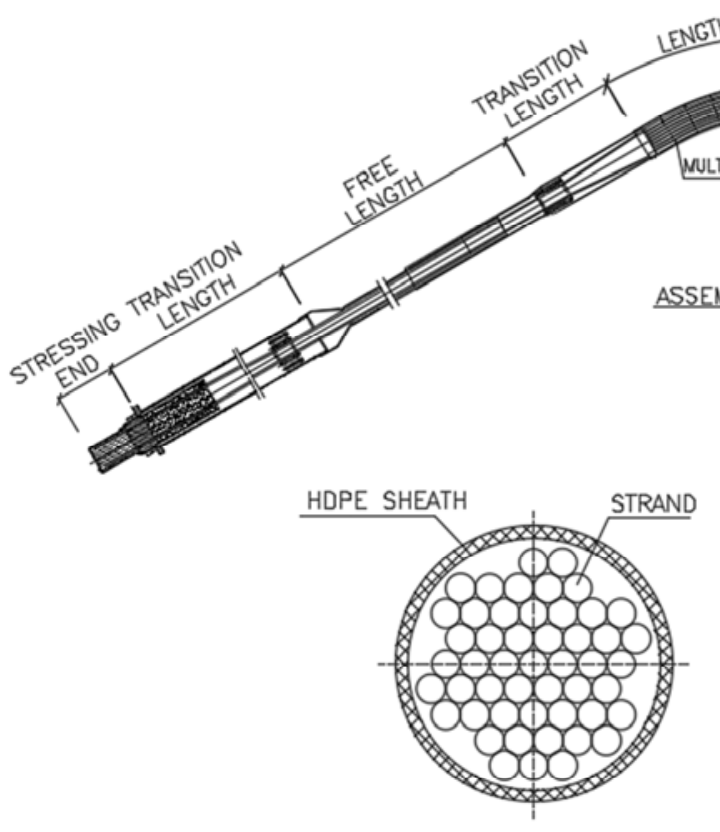

SSEMBLY OF STAY CABLES
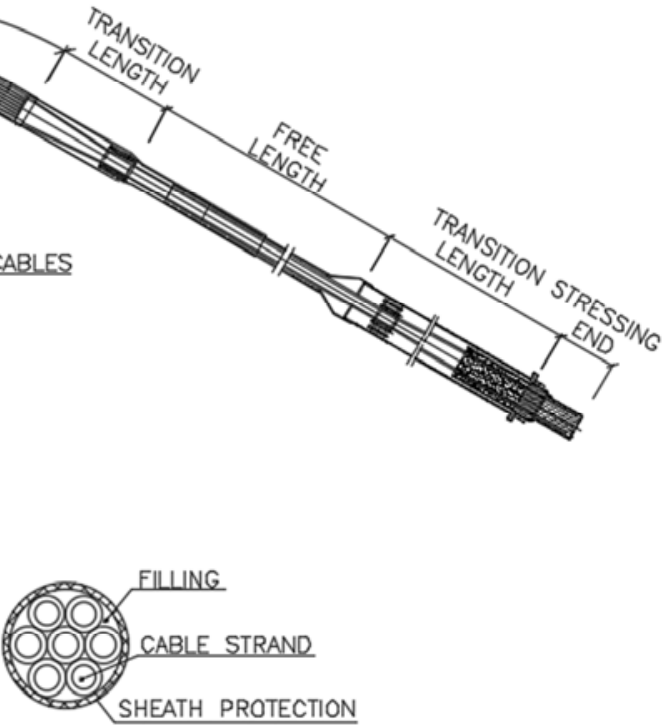

STAY CABLE

STRAND

Figure 7. Stay Cable Details.

\subsection{Stay Cables Crossing Over the Pylon}

For hollow pylon section, the commonly used stay cable anchorage types included anchor block, steel anchor beam, and steel anchor box etc. Considering the space required for stay cable tensioning, the pylon dimension is generally large. The adoption of deviation saddle at the pylon for the stay cable crossing over can minimize the dimension of pylon and hence the pylon quantities. The pylon is in solid concrete sectionfor ease of construction. The stay cables are anchored to the deck edge beams by means of anchor blocks.

\subsubsection{Pylon Concrete Compressive Stress at the Base of Deviation Saddle}

The pylon concrete compressive stress at the base of deviation saddle consists of two components: i) total compression contributed from saddles above the pylon section to be checked, and the stress is equal to the compression divided by pylon section area, ii) the direct local bearing stress from the saddle on the concrete, which is contributed from the vertical component of stay cable force. From the calculation finding, the pylon concrete compressive stress at the base of saddle is in the range $6.3-9.9 \mathrm{MPa}$ which is less than the design code allowed limit $0.4 \mathrm{fcu}=20 \mathrm{MPa}[6]$.

\subsubsection{Check of Slipping between Saddle and Pylon Concrete}

During the bridge construction stage, operation stage and under seismic actions, there will be loading conditions causing large force difference in one stay cable supporting the main and side spans at the two sides of the pylon. Therefore, it is necessary to check the effect of deviation saddle slipping over the pylon concreteso as to prevent such occurrence. The resistance of slippingis contributed by the side friction between saddle perimeter and the pylon concrete. The slipping resistance between the saddle and pylon concrete should satisfy the requirement in following formula:

$$
\triangle \mathrm{T} \leq \Sigma \mathrm{A} \tau
$$


Where: $\Delta \mathrm{T}=$ difference in stay cable force at two sides of pylon $(\mathrm{kN})$

$\mathrm{A}=$ contact area between perimeter of saddle and pylon concrete $\left(\mathrm{m}^{2}\right)$

$\tau=$ shear capacity between saddle and pylon concrete $(\mathrm{kPa})$

Considering the compression force between saddle side face and pylon concrete is small, the design can neglect this part for a more conservative result. To simplify the calculation, the differential force between two sides of saddle can be taken as the difference of the maximum and minimum stay cable forces of either side. From the calculation finding, the slipping shear stress between saddle and pylon concrete is equal to $0.14-0.48 \mathrm{MPa}$, which is less than the allowed limit $0.6 \mathrm{MPa}$ as specified in design standard [6].

\subsubsection{Check of Slipping between Stay Cable and Saddle}

During the bridge construction stage, operation stage and under seismic actions, there will be loading conditions causing large force difference in one stay cable supporting the main and side spans at the two sides of the pylon. As such, it is necessary to check the effect of stay cable strands slipping over the deviation tubes inside saddle to prevent its occurrence.

The slipping resistance between stay cable strands and deviation tubes should satisfy therequirement in following formula:

$$
\mu=-\frac{1}{\theta} \ln \left(\frac{T 1}{T 2}\right) \leq[\mu]
$$

Where: $\mathrm{T} 1 \& \mathrm{~T} 2$ are the stay cable forces at the two sides of saddle, $\mathrm{T} 1<\mathrm{T} 2$

$\Theta=$ angle at center of circular arc of deviation tube (rad)

$\mu=$ coefficient of friction between cable strand and deviation tube

$[\mu]=$ allowable coefficient of friction between cable strand and deviation tube

From the calculation finding, the evaluated coefficient of friction between cable strand and deviation tube is equal to 0.021-0.204 which is less than the stay cable supplier VSL provided test result $[\mu]=0.4 / 1.5=0.266$ ( 1.5 is the factor of safety for ULS)

\section{Conclusion}

The Second Penang Bridge in Malaysia is a super long sea crossing bridge to be designed in compliance with the British Standard. The main bridge is a two-pylon three-span prestressed concrete cable-stayed bridge, with span arrangement of $(117.5+240+117.5) \mathrm{m}$. The main girder adopted the ladder type concrete deck "built up" section which is easy for construction \&maintenanceand can also satisfy the heavy traffic load and prestressed concrete structural requirements as specified in British standard. Ameticulous calculation method was used which can accurately reflect the structural behavior of the main deck diaphragms and avoided the possible design safety risk. The bridge deck erection employed the rear supported form traveler and adopted different construction timing for edge beams and deck top slab in the same segment, which did not only reduce the form traveler weight but also minimize the stresses in the deck girder during erection stages. The stay cable crossing over pylon using the deviation saddle can effectively simplify the construction processes and also achieve a pleasant aesthetic. The bridge construction started in November 2008 and the main bridge deck closure segment was poured in April 2013. The bridge was completed and opened to traffic on 1 March 2014.

\section{References}

[1] Malaysia Second Penang Bridge Detailed Design [Z], CCCC Highway Consultants Co., Ltd., Beijing 2010

[2] Sham R, Fang ZR, Meng FC, The Second Penang Bridge, A Glorious Chapter in Modern Bridge Engineering [M], Beijing, China Construction Industry Publication, 2015

[3] Zhan JianHui, Peng Xiao Bin, "Long Span Composite Cable-Stayed Bridge Design Scheme Studies", Bridge Construction Journal, P.85-91, Volume 46(4), 2016

[4] Liu Yan Fei, Zhu An Jing, Kang Xiao Ming, "Xiangyang East West Hanjiang Long Span Bridge Crossing- Main Bridge Design", Bridge Construction Journal, P.94-98, Volume 47(1), 2017

[5] Xie Wei Liu, "Prestressed Concrete Cable-Stayed Bridge Ladder Type Main Deck Structure- Section Stress Distribution and Effective Width Studies", China and Overseas Construction Journal, P.152-155, Volume 2006(5)

[6] BS5400-4: 1990, Steel, Concrete and Composite Bridge, Code of Practice for Design of Concrete Bridges

[7] Yu Chao, Hu ZhiJian, Wu Da Jian, "Long Span Concrete Cable-Stayed Bridge Deck Erection Stress Analysis and Crack Prevention Technology Studies", Journal of Wuhan Polytechnic University (Transport Science and Engineering Edition), P.1073-1077, Volume 40(6), 2016

[8] Wang Rong Xing, "Single Plane Prestressed Concrete Partial Cable-Stayed Bridge- Construction Technology Analysis", Transport World Journal, P.148-149, Volume 2017(4)

[9] Wang Wen Xia, GuoQiang, You XinPeng, "Concrete Cable-Stayed Bridge Erected by using the Cable Supported Form Traveler", Journal of China and Overseas Highway, P.95-99, Volume 2011(2)

[10] XieZe Fu, "Analysis of Shear Lag Effect at Ladder Deck Type Cable-Stayed Bridge Erected by Balanced Cantilever Erection Method", Journal of Bridge Construction, P.14-19, Volume 43(4), 2013

[11] Chen Liang, Shao Chang Yu, "Effects of Creep and Shrinkage at Ladder Deck Type Cable-Stayed Bridge Erected by Balanced Cantilever Erection Method", Journal of Bridge Construction, P.74-78, Volume 45(1), 2015

[12] Hou Man, Qu Chun Sheng, Liu Bo, "Malaysia Second Penang Bridge- Cable-Stayed Bridge Diaphragm Design and Analysis Method", Journal of World Bridge, P.26-29, Volume 40(4), 2012

[13] Zhang ZuoJie, Wang RongHui, Zhen Xiao Xia, "Parallel Strand Stay Cable Force Measurement Method Evaluation", Journal of Bridge Construction, P.42-47, Volume 46(2), 2016 